\title{
HISTORICAL SURVEY OF THE NON EUROPEAN ARMY SERVICES OUTSIDE OF THE UNION OF SOUTH AFRICA (PART 1)
}

\author{
edited by \\ Noëlle Cowling \\ Documentation Service, SADF
}

\begin{abstract}
The Union War Histories Committee was established by General J.C. Smuts in 1941, with the purpose of recording the Union Defence Forces' role in the Second World War. The committee, under Colonel (Professor) J.A.I. Agar-Hamilton, produced a large number of manuscripts which deal with various facets and activities of the Union Defence Forces. These manuscript histories are in the custody of the Documentation Service, SADF and provide a fruitful source of information for many researchers. The following paper has been taken from a manuscript entitled "Historical Survey of the Non European Army Services outside the Union of South Africa". Although the manuscript was written from a rather patronising viewpoint, the reader should examine the paper in terms of the context and the times in which it was written. Sensitivities in this regard have been overlooked in the interests of making available an unpublished manuscript dealing with a topic which has to a large extent been neglected in South African military historiography.
\end{abstract}

\section{INTRODUCTION}

This account is not exhaustive, but is nevertheless a fairly comprehensive survey of the history, organisation and administration of the Cape Corps (CC) and Native Military Corps (NMC) in the East African, Middle East and Italian Campaigns during the years 1940 to 1945 .

In outline, the survey completely covers all Non-European Army Services (NEAS) activities in the foreign campaigns during the war. It is also complete in major detail in respect of the periods the writer ${ }^{2}$ served as Staff Officer (as recounted under "Organisation - Direction of the NEAS Effort") on the various headquarters.

The activities of the Cape Corps and the Indian and Malay Corps (IMC) have not been described separately. This is in conformity with the administrative procedure adopted from the outset. In the field these two Corps have always been regarded as one and have been known as the Cape Corps. Reference to the Cape Corps therefore includes the Indian and Malay Corps.

Furthermore, the Directorate of Non-European
Army Services (DNEAS) was set up on 12 Jul 40 , to organise, administer and direct all NEAS activities. Reference to the NEAS therefore includes the Cape Corps, Indian and Malay Corps and the Native Military Corps.

\section{EARLY HISTORY}

The Cape Corps was formed on 8 May 1940 under the command of Colonel C.N. Hoy, DSO and started with the training of Coloureds in the Kimberley area. Recruits were drawn from all parts of the Union.

On 26 June 1940 the Indian Corps was formed under the command of Colonel Morris, CMG, DSO and commenced training on the Crown Mines property outside Johannesburg. Although it was initially intended that this Corps consist of South African Indians only, it soon became apparent that insufficient Indian volunteers would be forthcoming. And so, from the very start, volunteers for this Corps included Indians, Cape Malays and Coloureds. It was, therefore, not an "Indian Services Corps" and it was decided on 19 December 1940, to change the name of the Corps to the Indian and Malay Corps. 
It was unfortunate that two separate Corps for this section of the community should ever have been formed, as they drew their recruits from the same source and, bar a negligible number of Indians from Natal, had everything in common and should have formed one Corps.

The Native Military Corps was formed on 1 July 1940. Rrecruits for this Corps streamed in from all over South Africa, but mostly from the Northern Transvaal. mentality and quality of the men they were called upon to lead.

At the outset the Cape Corps consisted of five motor transport companies; the Native Military Guards (as the NMC was previously known) comprised four battalions; while the Indian Services Corps numbered several battalions. This provided an interesting comparison to the NEAS at its peak, when it consisted of 120000 men trained as stretcher bearers, medical aids and hospital orderlies, motor transport drivers,

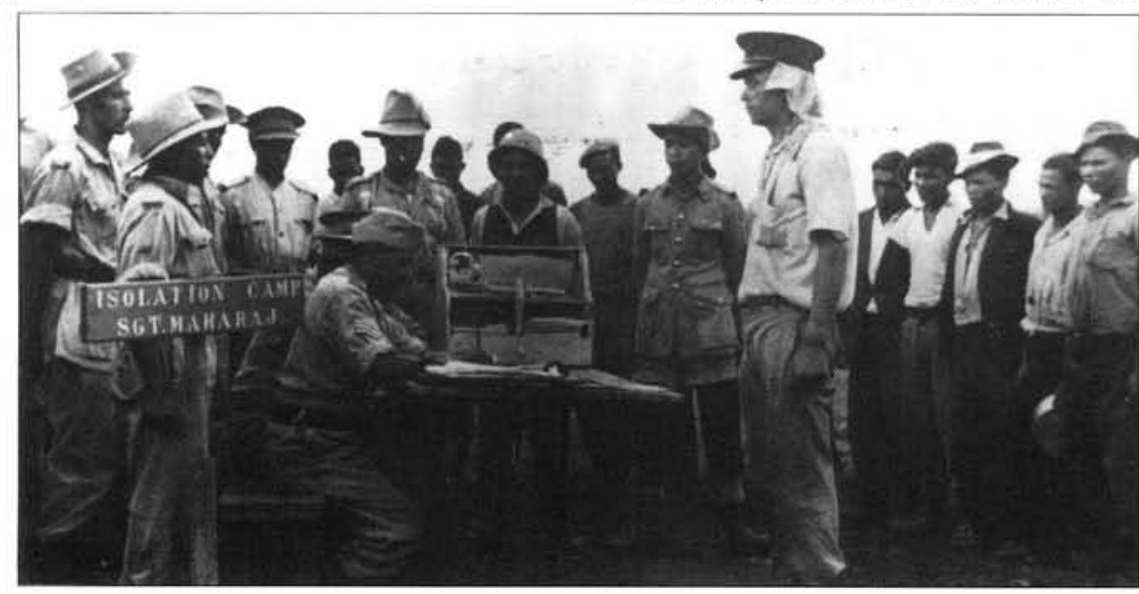

NEAS soldiers enlisting for service at an isolation camp.

On 12 July 1940, all of the Non-European services were combined under one Director. The first Director NEAS was Lieutenant Colonel B.W. Martin who had been the Director of $\mathrm{Na}$ tive Labour for the Witwatersrand. Lieutenant Colonel Martin was assisted by an Assistant Director (A/DNEAS), Major F. Rodseth, MBE.

The functions of the Director and his staff were to coordinate and direct the services of the Cape Corps, Indian and Malay Corps and the Native Military Corps as required by the Chief of the General Staff on behalf of the Government.

It must be obvious to any student of South African affairs that the problems which were bound to beset the NEAS would be many and varied. And they were. In view of the complex nature of these new Corps, it should have been clear that only the very best leadership would be good enough to make this new branch of the Union Defence Force a success. More was the pity, therefore, that the selection of White officers and non-commissioned officers for the NEAS should not have been more discriminating and that this branch of the service should have been used throughout to absorb redundant officers and NCOs from other Corps. Many such men were unsuitable to lead in the NEAS. Many were not interested and seldom really tried to understand or appreciate the mechanics and despatch riders, guards and provost, skilled artisans in all the building trades, cooks and waiters, typists, telephone operators, highly skilled linesmen in signal units and a multitude of other important occupations.

\section{DEPLOYMENT OUTSIDE AFRICA}

As the lines of communication in East Africa were long and hazardous, much mechanical transport was needed to keep the victorious and rapidly advancing South African and Allied troops supplied. This provided the first opportunity for NEAS members to serve outside the Union. The opportunity was welcomed by the personnel, all of whom - recruits, officers and NCOs alike - worked with a will to get the motor transport units organised in record time. This proved to be a stupendous task as the black recruits were not familiar with military discipline and procedure; few prior to training were capable of a standard of motor transport meeting military requirements; and futhermore training facilities, equipment and personnel were lacking. Motor Transport units, however, were required immediately in East Africa and this left little time for training. The first of the Cape Coloured and Indian Malay Corps' left South Africa by train for Broken Hill on 3 September 1940. At Broken Hill they were supplied with their vehicles and equipment and set out for Nairobi over the hazardous roads of Northern

In the old colony of Northern Rhodesia, now Zambia. 
Rhodesia, Tanganyika and Kenya. The route wound through Mpika, Mbeya, Inringh, Dodomo, Arusha to Nairobi, through the tropical lake district and over muddy plains of Tanganyika and Kenya. But in spite of the inexperienced drivers, broken springs and mud, the convoys came through regularly at intervals varying between two to three weeks.

In Nairobi the motor transport companies separated. Some were sent in support of the fighting forces advancing along Lake Rudolph; while others were committed to the lines of communications work between Nairobi, Nanyuki and Wajir; and some moved south to Mogadishu before swinging inland again on their way to Addis Ababa via Jijiga, Harrar and Deridawa. Other drivers, still, followed up with supplies for the forces advancing through Moyale and Mega, through the lake area on a direct route to Addis Ababa.

By March 1941, the Cape Corps motor transport units in East Africa and Abyssinia had increased to 23, and the first four Cape Corps companies - A,B,D and E - had gone overland, along the Nile route to Eritrea, where they operated in support of the British and Indian troops. Some companies had swung left from Nairobi and were operating between Nairobi and Juba and in the Lake Rudolph area, supplying large numbers of troops in that theatre.

Later in the war, all the motor transport companies in Kenya found their way up to Abbysinia where they operated throughout that campaign and moved forward to Eritrea where they were "in at the kill" at Keren.

The problem of inexperienced drivers, which had been formidable at the beginning, righted itself with amazing rapidity. Officers and men were keen and soon the companies were welded into first class units which could be depended upon to deliver the goods in spite of bad roads, adverse weather conditions, broken springs, and shortage of spares and trained mechanics.

The following appreciation from Lieuteant General William Platt, the general officer commanding the Sudan Force, addressed to the Chief of the General Staff in Pretoria, reflects upon the important contribution these motor transport units made to the Allied war effort in the Abyssinian and Eritrean campaigns :

"Last time General Smuts was here I told him how splendidly the South African Cape Companies had worked for us ever since they arrived in the Sudan in the middle of January. They continued to do so and they continue to do so. It was due to the great effort of our M[otor] T[ransport], including your Companies, that enabled us, after many hard days' fighting, to smash the enemy at Keren and force him to withdraw 300 miles from that battlefield. After Keren, they naturally contributed their fair share to our pursuit of the enemy and the capture of Massawa.

The following facts have been given to me, at my request, by the Commander of my L[ines] of C[ommunication]:

'The loads which have been put forward along the $L$ of $C$ have been tremendous, and although they have not all been carried by the Cape Companies, a very large percentage has been transported by them.

'Up to the 17th March, 1941, they were doing 150 miles two days out of three, and loading up on the third day. The distance was then reduced to 100 miles, only to be increased to 150 miles again on the 28 March. They have done this day in and day out seven days a week.

'They have had serious trouble with maintenance in breakages of springs and wearing out of tyres. Both these were due almost entirely to bad roads, which have only recently been improved, and are not yet perfect. But in spite of that the Cape Companies have kept up the high availability of MT, and have used much ingenuity to do so.'

I think you will agree the above speaks of itself.

I shall be grateful if you can tell General Smuts of the above and express to him the gratitude of all ranks serving under me for the work and spirit of South African Cape MT Companies....."

Following closely on the heels of the Cape Corps motor transport units, were the first $\mathrm{Na}$ tive Military Corps troops who arrived in East Africa to join the 5th South African Infantry Brigade as drivers, cooks, batmen, hygiene personnel and stretcher bearers. They numbered approximately 1000 , but were later increased to about 1500 . This was really the commencement of the "Dilution Policy" outside South Africa. It was an entirely new experiment whereby White units were diluted with Blacks in order to save combat manpower for the multitude of new formations created in the rapidly expanding South African Army.

As expected, difficult "teething troubles" were encountered. The two main obstacles to overcome were, once again, the instruction of un- 
trained personnel in their new and complex duties; and the prejudice of so many White South African soldiers against Black soldiers as comrades-in-arms.

A further addition to the NEAS formations in East Africa was the arrival of the Cape Coloured Works companies. By April 1941, seven of these units had arrived and were at work over an area as far apart as Gilgil, Londiani, Nanyuki, Mogadiscio, Harrar and Berbera. These companies were employed on all types of construction work, but mostly on the construction and maintenance of army camps and field hospitals.

The following communication dated 19 March 1942, from Major E.J. de Lathenbiere of the South African Military Mission (NEAS Section) to the East African Command, and addressed to the Officer Commanding 156th Cape Corps Works Company, is typical of the tributes paid to these servicemen:

"I don't feel I expressed with sufficient warmth my sincere appreciation of the really magnificent work your unit has done in Somaliland. I am sure they will be remembered for many years by the works they have carried out. It has been a great pleasure to work with such a unit."

Apart from those men already mentioned, there were also substantial numbers of NMC serving in other non-divisional units such as $15 \mathrm{Ambu}$ lance Company and 36 Water Supply Company of the South African Engineer Corps (SAEC).

The Administrative problems connected with the deployment of the NEAS personnel outside the Union became, predominantly, the concern of the newly created Deputy Directorate of the NEAS. Lieutenant Colonel Martin, who had in the meantime been replaced in Pretoria as $\mathrm{Di}$ rector NEAS by Senator Colonel the Hon. E.T. Stubbs, was nominated for the important post of Deputy Director (DDNEAS) and set up his office in Nairobi in November 1940. He was joined early in 1941, by his former assistant, Major Rodseth, and a small staff.

This Deputy Directorate, created as an integral part of the Administrative Branch but lacking executive authority, assumed the onerous responsibilities of carrying out all "A" Branch functions concerning the administration of NEAS members in the different units. The magnitude of the task becomes obvious when one remembers that no satisfactory or tried rates of pay (particularly extra duty pay), clothing scales, ration scales, leave privileges or facilities, reinforcement and transit systems, hospitalisation or penal system in respect of Cape Corps and Native Military Corps personnel existed.

However, the problems were tackled with vigour and determination by the DNEAS and his staff and in spite of the difficulties, excellent results were achieved. Reinforcement and transit depots for the CC and NMC were set up at Tigoni (outside Nairobi) and Gilgil, where a considerable amount of reshuffling, disciplinary and regimental training was carried out.

The conclusion of the East African campaign saw approximately 5500 members of the CC engaged in transport work, a further $1500 \mathrm{em}$ ployed on constructional work and about 1600 members of the NMC in the 5th Brigade and the non-divisional units in that theatre of operations.

Victory in Abyssinia and Eritrea sounded the note for the great trek to the Middle East where the German troops had reinforced the badly mauled Italian armies. The exit of NEAS servicemen began with the epic march of 103 and 105 IMC companies from Kenya to Cairo. These units left Kenya in June 1941 and arrived in Cairo in July 1941, having covered the complete distance of over 2000 miles of swamp and desert in just one month. These two units were followed by the NMC with the 5th Brigade. Most of the other units lingered on in East Africa, Abyssinia and Eritrea, where they were employed on vital supply work and clearance of war material being shipped to the Middle East, until the end of 1941 when they began arriving in the NEAS Depot in the desert at Garawi, about 25 miles North of Cairo.

With the arrival of about 9000 NMC with the 2nd South African Division in June 1941, it became necessary to establish the Deputy Directorate of NEAS with the UDF Liaison Office (later UDF Administrative Headquarters MEF) in Cairo. To this end, Lieutenant Colonel Martin and Major Rodseth left for Cairo in June and July 1941 respectively, and Major W.G. Trollip remained in Nairobi to wind up the work of the Deputy Directorate in that area.

At the end of 1941 the requirements of the UDF in the field in so far as NEAS soldiers were concerned, had completely changed. The 5th Brigade had disintegrated in the fierce battle at Sidi Rezegh, and the whole of the 1st South African Division required reinforcements in large numbers. As there were then two South African divisions committed to battle with the Desert (later 8th) Army, it was impossible to maintain them without the permeating of NEAS members on a large scale. 
This urgent need for reinforcements resulted in the disbandment of the many fine Cape Corps motor transport and works companies which had performed so splendidly during the East African campaign. It was a hard blow to officers and men alike and damped the enthusiasm of many who failed to appreciate the necessity for breaking up these units. However, it had to be done, as drivers in particular were required in the divisions. The units were disbanded on their arrival at the NEAS Depot and the men were drafted into the 1st Division as drivers, mechanics, cooks, batmen and hygiene personnel.

Of all the motor transport and works companies which had come through East Africa, only $A, B, D, E$ and $N$ companies were still intact in June 1942. The first four had been delayed in Eritrea, while N Company (later $133 \mathrm{SA}$ Reserve Motor Transport Company (V) CC) had been given the important assignment of ferrying vehicles to Turkey. This unit was employed on these ferrying duties for approximately six months and moved thousands of vehicles from the Nile Delta area through the Sinai desert, Palestine and Syria to Aleppo where they were handed over to Turkish officials. An example of the strange duties periodically assigned to this the British government to the Turkish Army - to the Turkish Consul in Aleppo four days later.

With the breaking up of the Cape Corps works companies, the artisans and some of the drivers were used to dilute the 25th, 27th, 30th and 31st Road Construction companies and the 32nd Road Maintenance Company. Each of these units was given about 70 Cape Corps members.

In the meantime the number of Blacks in the Middle East was further increased by the arrival of 220 NMC staff with 101 South African (NonEuropean) General Hospital; 14000 with 44 Water Maintenance Company SAEC; over 100 CCs with 44 Railway \& Harbours Base Maintenance Workshop at Suez; and about 1000 specially selected NMC (who had worked in the Gold Mines) with 61st Tunnelling Company to build the tunnel at Cheka, 11 and 13 Field Companies SAEC (with about $200 \mathrm{CCs}$ each), as well as several large drafts of CC and NMC reservists at the NEAS Depot.

In addition to the units enumerated above, there were at the beginning of 1942, also NMC and $\mathrm{CC}$ serving with the Line of Communication

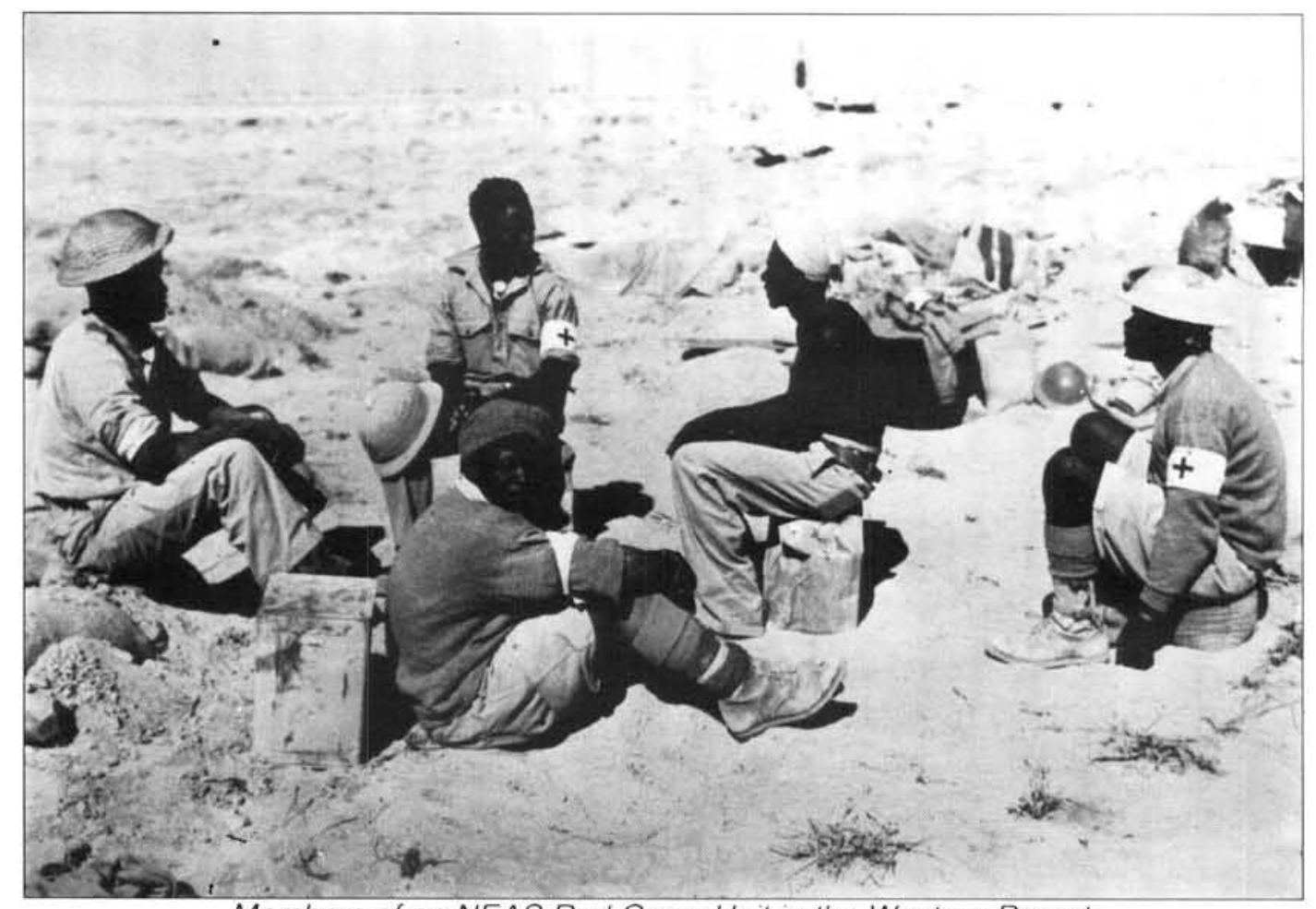

Members of an NEAS Red Cross Unit in the Western Desert.

company was the occasion in June 1942, when a party of selected drivers were called upon to drive 18 beautiful Packard Sedans of the latest models from the vehicle park at Tel-El-Kebir to Aleppo. Eighteen Cape Corps drivers of 133 Company were selected for the job and they delivered the Sedans - apparently a gift from hygiene units and hospitals, and the first CCs were being employed with the rapidly increasing South African Air Force units in the Middle East. The members of the Cape Corps with SAAF were employed on ground defence duties (a ground defence flight of 68 men under the supervision of the Ground Defence Officer and 
a White staff sergeant was attached to each squadron for guarding the aircraft, equipment and camp area; their duties corresponded to those of the RAF Regiment in respect of RAF Squadrons) and in other general duties such as drivers, cooks, scullions, waiters, hygiene personnel and batmen. The number of CC men undertaking general duties in the different squadrons varied between 60 and 80 . The Squadrons which at the beginning of 1942 were diluted in this way were No.1, 2, 4, 5, 12, 21, 14,40 and 60 Squadrons and 3 Wing SAAF.

By April 1942, the number of NMC and CC employed with the Union Defence Force and the South African Air Force units stood at over 28000 . This was the largest number of NEAS personnel ever to serve with South African forces in the Middle East and Central Mediterranean theatres during the war.

At that time the greatest difficulties were also experienced with regard to administration, and the most important developments regarding the future employment of non-Whites in the Union Defence Force took shape.

It had become apparent that many units of the 2nd South African Division had absorbed more NEAS soldiers than it had place for, and that most of the diluted units were experiencing difficulties with untrained and insufficiently trained personnel. The adverse influence a small percentage of recalcitrant and recidivist soldiers had on discipline, morale and efficiency in most units, was another serious problem which had developed since the inception of the dilution policy.

At about the time of the fall of Tobruk (June 1942) the morale, efficiency, discipline and prestige of the NEAS in the Middle East theatre were at the lowest ebb. The causes were:

(a) The disbandment of the motor transport units and Works companies which had developed a fine esprit de corps during their operations in the East African Campaign.

(b) The effect of idleness on over 4000 NMC and $\mathrm{CC}$ left out of battle when the 2nd Division went into action;

(c) The difficulties experienced with untrained and insufficiently trained personnel; and

(d) The existence of relatively small numbers of recidivists who were exercising an undesirable influence on other members of their units. Some of these men had developed criminal records in the field, but at least $50 \%$ could easily have been eliminated in the Union had the selection for service outside South Africa been more conscientious and discriminate.

It was obvious that energetic and effective action had to be taken immediately to remedy this serious state of affairs, and to prevent the NEAS from developing into a drag instead of a valuable asset to the UDF war effort; and also to maintain and enhance the prestige so heroically won and treasured by Blacks and Coloureds who had served with distinction in the First World War and the campaigns of the Second World War.

Those concerned with the direction of the NEAS war effort threw themselves wholeheartedly into the struggle and laid the foundations on which a sound future was built. From then on the NEAS in the field never looked back and steadily gained in efficiency, discipline, morale and prestige, in spite of insuperable difficulties encountered at times.

Steps taken to overcome the difficulties these were:

(a) the withdrawal from units of redundant and unsuitable personnel for training and reclassifaction into duties for which they were suited;

(b) the creation of specialist training branches at the NEAS Depot at Garawi, such as the Driving and Maintenance School, Cookery School, and the Artisan Training Centre which was run with assistance from the SA Engineer Corps.

(c) the formation of purely Black units under officers and senior White NCOs only, such as the NMC motor transport companies; and

(d) the disposal of recidivists.

The DDNEAS approached the general officer commanding Middle East, when redundant NMC became available in large numbers at the end of March 1942, to ascertain what type of service was mostly required. The answer came immediately; motor transport units were urgently needed. In fact the need for motor tansport, to keep Allied troops in the desert the front line was then at Gazala - supplied, was so great that the General Headquarters was prepared to assist in every way possible in the formation of such units.

Defence Headquarters in Pretoria approved the 
formation of ten NMC reserve motor transport companies $^{4}$ from the surplus personnel available in the Middle East theatre. An immediate start was made with the training of drivers at the Driving and Maintenance Wing established under the able direction of Major Knudsen a mechanical transport expert from General Motors in Port Elizabeth.

The first unit 5 commenced operations on 1 April 1942. It was pushed into service on the highly specialised job of supplying the South African road construction companies, which were keeping the roads in repair in the Western Desert. One particularly interesting experiment with these NMC motor transport companies was the attachment of a British Mechanical Workshop Section consisting of 42 British artificers under their own Officer, to each unit. This was done in view of the acute shortage of motor mechanics in the Union Defence Force. The experiment proved an unqualified success. The British soldiers were much impressed by the eagerness to learn and good nature of the NMC drivers, with the result that there was practically no racial difficulty at all.

With the tragic reverse suffered by the Allied Forces at Tobruk in June 1942, the need for NMC motor transport became even more vital as about one third of the Allied transport had been lost during the retreat. The formation of the NMC transport units was speeded up and by the end of October 1942, 203, 204, 205, 206, 207, 208 and 209 Reserve Motor Transport companies (V) were operating in the Western Desert and Delta areas. Each company operated with 120 three-ton reserve trucks, workshop vehicles and run-about.

Number 209 Company had the distinction of being added to the 8th Army Order of Battle immediately after its formation in October 1942, and of operating directly in support of the 8th Army until the fall of Tripoli on 25 January 1943. It therefore completed the long trek of over 1 600 miles from Cairo to Tripoli in three months on a fully operational basis. This company shared, with 203 and 206 Motor Transport companies, the distinction of qualifying for the treasured 8th Army clasp to the Africa Star.

At the conclusion of the victorious North African campaign, General Headquaters Middle East addressed a special letter of appreciation to the General Officer Administration UDF, praising the outstanding work of these units and acknowledging that without the material assist- ance of these companies which had added a daily average of over 800 three tonne carriers to the transport availability of the Middle East forces, the supply organisation and advance of the 8th Army could not have proceeded as successfully as it did.

The fall of Tobruk was a sad and a hard blow to the UDF. Like other corps, the NEAS suffered heavily. It lost over 3000 of its best men. The strengths of the various formations were, however, built up again and this time with better trained and more reliable and more experienced men than had hitherto been available. When the victorious campaign of the famous 8th Army began on 23 October 1942 there were about 18 000 Cape Corps and Native Military Corps personnel operating either directly or indirectly in support of the Army in the Delta area or in the Western Desert. The approximate numbers and most notable formations in which they served, were:-

\section{CC and 1000 NMC in 1 SA Division \\ 3000 NMC in MT formations \\ $15000 \mathrm{CC}$ and NMC with SA formations \\ 1000 NMC with medical units \\ $3000 \mathrm{CC}$ and NMC in SAEC units \\ $500 \mathrm{CC}$ and NMC in Technical Service units \\ $500 \mathrm{CC}$ and NMC in Signals units \\ 2000 CC and NMC on Headquarter guards and provost duties \\ $1000 \mathrm{CC}$ on POW guard duties}

Non-European Army Servicemen with units such as 203 and 209 motor transport companies, 46 Survey Company SAEC, SA Army Signals Company, 11th and 13th Field companies SAEC, Corps Troops SAEC, 25, 27, 30, 31 and 32 Road Construction companies, and 157 and 158 Works companies, as well as about 500 NMC in the Railway Construction Group and approximately $1500 \mathrm{CC}$ and NMC with 3 and 7 SAAF Wings and Squadrons, completed the long trek of about 2000 miles from El Alamein to Enfidaville (Tunisia) where the last grim battles were fought.

The exploits of the South African Army and Air Force which contributed so splendidly towards the final defeat of the Axis Forces in Africa are too well known to need repetition here. Suffice it to say that over $5000 \mathrm{CC}$ and NMC troops in more or less equal proportions, were in at the kill with the South African units which were spread out between Tripoli and Tunis when the final surrender came received full credit for their

This was 203 Reserve Motor Transport Company (V) NMC. 


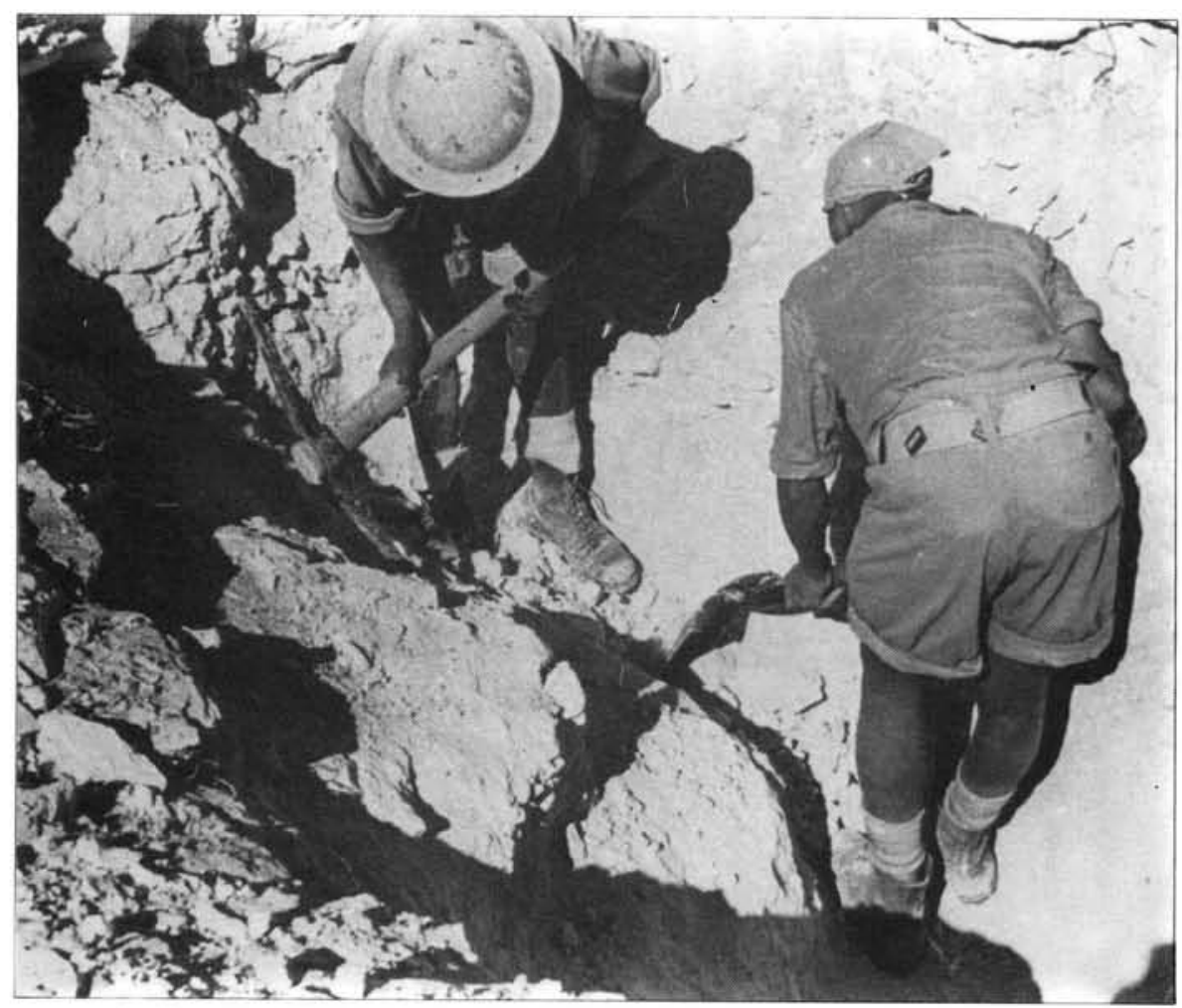

Indian and Malay Corps soldiers digging trenches in the desert.

work from the South African and Allied commanders alike.

The 1st South African Division, which had been withdrawn from operations after the battle of El Alamein, returned to South Africa at the end of 1942. Approximately $2000 \mathrm{CC}$ and 1000 NMC returned to South Africa with the Division. By this time there was a change of attitude towards the employment of NEAS personnel. Where at first there was scepticism and prejudice there was now praise and Blacks and Coloureds were accepted as an integral part of the Division. Even General Dan Pienaar who had previously opposed the employment of NEAS members in the 1st Division expressed satisfaction with and appreciation of their serv- ices when the Division was withdrawn, and warmly praised their splendid contribution during the battle of Alamein.

The bulk of the Cape Corps and Native Military Corps were, however, not fortunate enough to be the vanguard of the victorious forces, but they worked splendidly on gruelling and monotonous, but nevertheless vitally important duties in the desert and delta to keep the army supplied over enormous distances.

So came to an end, in May 1943, the first phase of one of the most difficult but brilliant campaigns in history. The Axis forces had been driven from the borders of Kenya and finally defeated in Tunisia. The NEAS soldiers

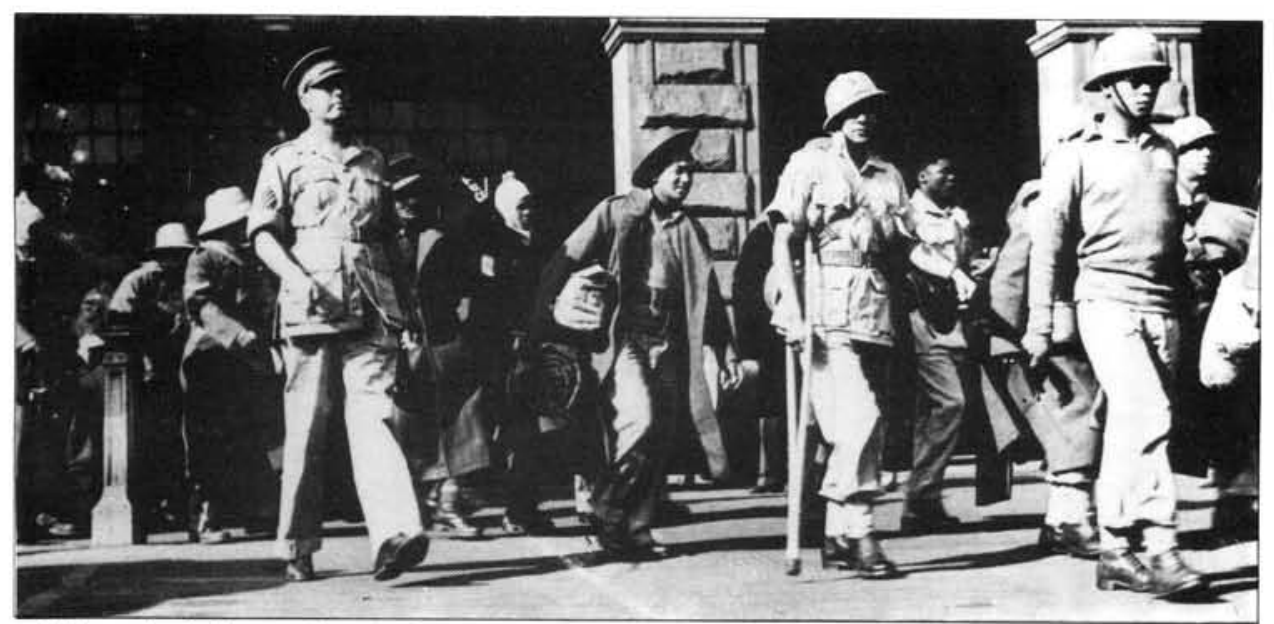

Wounded Cape Corps Servicemen at Pretoria Station on their return from the Middle East. 
were there in large numbers from the beginning to the end. During this time of grave peril they served their country faithfully and well in the best traditions of South African History.

\section{INVASION OF EUROPE}

Following immediately on the defeat of the Axis forces in North Africa, came the reorganisation of the South African forces to participate in the coming invasion of Sicily and Italy. This raised the contentious point of whether the NEAS should be allowed to serve in Europe or not and, if sent overseas, on what duties should they be employed.

There were other difficulties too. Whites in the SAAF, Engineer and other non-divisional units, and Whites and Coloureds in the 1st Division had left the theatre for the Union for a period of leave. Some of the Black and Coloured soldiers who had been out of the Union for two years and longer, got a bit restive as they perceived equal facilities not being extended to them. However, UDF policy was then defined and required all UDF personnel not specially needed for Invasion units or special duty, to serve for three years before qualifying for Union leave. NEAS members soon reconciled themselves to this policy and carried on with commendable enthusiasm in spite of prolonged service.

However, the controversy on allowing nonWhites into Europe was not as easily solved. In spite of the confidence expressed and assurances given by the DDNEAS and by officers who had commanded NEAS formations successfully in East Africa, Abyssinia and North Africa, tremendous opposition was experienced from certain quarters. However, in spite of all the opposition, necessity soon determined the policy that Coloureds and Blacks would have to form part of the personnel of Invasion units as insufficient Whites were available to maintain the commitments undertaken.

It was felt by DDNEAS and other officers that there was no reason why NEAS soldiers would not be entirely successful in Europe. Brigadier Hingeston was a firm exponent of this view. His faith in the Non-Europeans and appreciation of their contribution to the UDF war effort had made him a staunch supporter of the NEAS. He was at that time Senior Air Administration Officer in the Middle East Forces. His firm policy was a great help to the NEAS and contributed materially towards the successful dilution of the many SAAF units.
The preparation for the Invasion units proceeded in earnest. Policy had been defined to the extent that all SAAF Squadrons and certain Engineer and Signal units, destined for service during the invasion, were to be diluted with NMC and CC personnel who had volunteered for service outside Africa.

SAAF formations which had hitherto employed both CC and NMC in what became known as "mixed dilution", shed their CC ground defence personnel when they proceeded out of Africa. This was done because an arrangement had been made whereby the RAF would provide ground defence personnel from the RAF Regiment to all SAAF formations in Europe in return for Cape Corps ground defence personnel to be provided by the SAAF for RAF units remaining in the desert.

This arrangement was a blessing in disguise. It provided highly trained ground defence personnel to the SAAF squadrons in Sicily and Italy, eliminated mixed dilution with the resulting difficulties in the SAAF and enabled the DDNEAS to concentrate on $C C$ ground defence men shed by the SAAF into what became 102 Cape Corps Battalion. This battalion was formed in June 1943 along lines more or less similar to an infantry unit, and provided valuable protection to the Allied Air forces in the Benghazi Bulge areas $^{6}$ from its inception until its dissolution for demobilisation in July 1945 .

Each Air Force unit destined for overseas service was provided with about 75 NMC men, who were known as "hands general duties". They were mostly employed on the menial duties performed by cooks, waiters, scullions, batmen and hygiene personnel. However, each complement included a certain number of transport drivers and aircraft refuellers, and later on fire fighters were included.

So keen were the NMC to serve overseas that, in spite of their pride and reluctance to do menial work after becoming skilled in occupations, many drivers volunteered to serve as batmen and on other general duties. The excellent response to the call for volunteers was all the more gratifying in view of the general shortage of NMC men in Middle East at that time.

When the NMC landed in Sicily with the first SAAF squadrons in August 1943, an automatic division of NEAS services and administrative work took place. Like all other Allied personnel participating in the assault on Europe, the members of the NMC came under the com-

At such famous aerodromes as Gambut, El Adem. Benina and Benghazi. 
mand of the Central Mediterranean Forces. We shall consequently have to deal separately with the NEAS soldiers in Central Mediterranean Forces (ie Italy and the area west of Tripoli) and Middle East Forces.

Let us follow the progress of Non-Europeans with the Central Mediterranean Forces.

3 and 7 Wings (with 3 squadrons each), together with 40 Squadron SAAF, landed in Sicily in August 1943. With them were close on 700 NMC men.

The wisdom of allowing Blacks and Coloureds to serve in Europe had often been queried and freely criticised. Critics eagerly spread rumours (most of them unfounded) of drunkenness among the NMC and the alarming consequences of fraternisation with the Italians. However, in most cases, the NMC settled down to do solid work in the air force squadrons which were supporting the 8th Army's advance through Sicily and up to the toe of Italy.

Problems concerning wine and women, nevertheless did come to the fore. Wine flowed freely and Italian women knew or observed no colour bar. Many economically-pressed women were only to willing to barter wine or ply their female trade for foodstuffs, soap or cigarettes. These problems were by no means peculiar to the NMC or the UDF; they were causing equal concern to all Allied forces. However, in view of the South African colour complex and the Union's laws prohibiting the supply of liquor to Blacks, they were considerably accentuated in the Union Defence Force. It was made clear to members of the NMC that Union law and customs still applied and were to be observed even though the Union forces were outside South Africa. Although allowed to have wine, non-White soldiers were told that drunkenness would not be tolerated and that Italian women were as inviolate as White women were in the Union.

Although the conditions were such that fraternisation could not be avoided or eliminated entirely, ${ }^{7}$ it never reached alarming proportions. Offenders were adequately punished and removed from the theatre. This firm policy had a salutary effect on those who remained behind.

Although every effort was made to familiarise South African servicemen with their new surroundings, local conditions were foreign and often bewildering to most of the NEAS personnel.
They were taken to see large cities and modern farming methods; they heard about ancient Roman culture and civilisation; and learnt that better living conditions, increase in personal prestige and higher social standing could be attained only through tolerance, consistent work and assimilation of knowledge over a sustained period.

The fifty members of the $\mathrm{NMC}^{8}$ with the SA Army Signals were, in September 1943, the first Black servicemen to arrive in Italy. Half of these were drivers, but they were not being used as such : some could not drive well enough and there were not sufficient vehicles. Idleness soon played havoc with their morale and some of the men took to alcohol and others made advances to women. As a result, the offenders were removed from Italy. However, it is gratifying to record that those who were not returned to the desert settled down so well that they earned praise from their unit and stayed with it until the conclusion of the Italian campaign.

As the advance continued the number of Blacks and Coloureds (mainly NMC) in Italy also increased, particularly after the arrival of further Air Force formations and Engineer units. Each "Invasion" Engineer unit brought with it about 20 Cape Coloureds as batmen, cooks, hygiene workers and scullions. However, the decision to attach these small numbers of CCs with these SAEC units was unfortunate for the following reasons:

(a) Colonel McLaren (Senior Engineer Staff Officer) stated openly that he thought it was unwise to send NEAS soldiers to Europe and only accepted them because the units were under-strength and could not move to Italy while short of personnel.

(b) Cape Corps reinforcements were at a premium at the time these men had to be provided and, as a result, their number included many details with formidable records who should never have left the Union let alone be sent to Italy. (Note: Out of approx 80 Cape Corps men supplied to the Railway Construction Group SAEC, at least three were subsequently involved in murder cases in Italy).

(c) They were not really essential to the units who could easily have replaced them (in view of the small numbers involved and menial nature of their duties) by local civilians or Union Defence Force Whites.

Many South African units occupied and, in numerous instances shared, public buildings and private residences

8 This is an approximate. 
All Engineer units were given the option of shedding their Cape Corps staff immediately after their arrival in Italy. The Railway Construction Companies, however, retained their these men mainly because they had received such excellent service from the large numbers of NMC they had dealt with in the Middle East. The Cape Corps could, however, not be compared with the NMC which had served with these units before and it must be recorded, regretfully, that they caused the Group an undue amount of trouble.

Although the number of men concerned was small, the principle involved was most important. Colonel Evans (commander of the Railway Construction Group) showed remarkable appreciation and sympathy for this problem. $\mathrm{He}$ realised that these difficulties could be overcome only by the advantageous and successful employment of Blacks and Coloureds by affording them adequate opportunities for work and recreation and by eliminating weaknesses through corrective punishment, tolerance and leadership. Colonel Evans, however, did not stand alone with this viewpoint.

Throughout this time, the NMC members attached to the SAAF were steadily increasing. In fact, so much so, that by the winter of 1944 there were over 2000 NMC men serving in 28 squadrons and other SAAF formations in the Central Mediterranean theatre. Their duties had also extended. Such important work as fire fighting and much of the motor transport driving as well as refuelling of aircraft, and assisting armament personnel were now entrusted to them. Because of the shortage of European cooks about 100 NMC cooks had also been flown up from the Union to augment the cooking staff. On the whole the NMC revelled in these additional responsibilities. Through constant application to their duties of whatever nature, the NMC had won a respected place for themselves in SAAF formations in Italy. When pilots had to go on raids at dawn they were woken by NMC batmen and served by NMC cooks and waiters. Most likely they were also driven to the landing strip by NMC drivers, and coming in to land after a raid the NMC fire fighters and crash crews were always on watchful standby in case a damaged aircraft came to grief on landing. The NMC felt that they had become an integral part of the SAAF squadrons and responded splendidly as a result of the confidence they received from the airmen.

It is not intended to create the impression that all difficulties connected with the NMC administration had been overcome. On the contrary many difficulties were magnified as more and more NMC arrived in Italy with the ever increas- ing number of SAAF Units. Progress was maintained in spite of difficulties. Although a selective policy was still being followed in providing NMC for Italy the demand increased tremendously and the field of selection decreased considerably. The stage had again been reached where untrained or insufficiently trained men were posted to units. This proved particularly difficult in the case of cooks and motor transport drivers. Experience had proved that they could not be trained in five minutes. Careful tuition had to be given over extended periods in proper training schools. The difficulty was partially solved by the arrival of more well trained NMC cooks from the Union who proved to be exceptionally good.

It was wisely decide not to restrict the privileges or liberties of the men, thereby punishing the innocent with the guilty but to weed out the small minority of drunkards, recidivists and malicious agitators. This policy proved successful throughout the Italian campaign. Had it been done in the Union, as consistently advocated by the deputy director of the NEAS, much precious time, manpower and transport, required to shunt recidivists backwards and forwards from the Union to the Middle East and Central Mediterranean theatres and vice versa, could have been saved. It would also have obviated much disciplinary action, and administering punishment in detention barracks and other punishment centres. It may be thought that it was impossible to do the sifting out in the Union. On the contrary it was relatively easy to pick out the recidivists and misfits at first sight. They could almost invariably be distinguished by their sloppy appearance, and conduct sheets.

As the battle became static at the beginning of the winter of 1943 the SAAF Units had settled down in the Foggia plains. All NMC were therefore concentrated in that area and it became necessary to establish a Non-European Leave and Transit Centre in the vicinity. Bari was chosen as the most suitable site because of its proximity to the ports of Taranto, Bari and Brindisi and the hospital and punishment facilities in that area. No 2 Non-European Leave and Transit Camp was established at Torre-AMare, 8 miles south of Bari on the sea. This camp proved to be of inestimable value as a reinforcement, transit and evacuation centre, a leave camp and a rehabilitation centre for soldiers who had resorted to crime or alcohol abuse. The rehabilitation scheme was, in fact, one of the most interesting NEAS schemes undertaken in Italy. Because of the scanty White staff provided for this camp of 500 capacity (2 Officers and 10 White NCOs - including the 
medical and motor transport staff) the camp had to be run mainly by the NMC and CC noncommissioned officers and this proved eminently successful. When a so called "undesirable" came into the camp he was given every opportunity of forgetting the past and turning over a new leaf. Instead of being treated like a criminal he was treated like a gentleman. $\mathrm{He}$ was given the same leave, recreation and canteen facilities as the other men and made to feel that he was a normal human being capable of good or bad conduct in varying circumstances. He was not regarded with suspicion, contempt or as a criminal. It was gratifying to see how men responded to such treatment. Many difficult individuals became rational men after a period in this camp and rendered excellent service on posting to other units. To achieve these results all members of the camp staff - Black and White alike - worked as a team. The CC and NMC non-commissioned officers, and the NMC chaplains together with the White Officers and non-commissioned officers worked entirely to make the organisation a success. To Captain C.R. Cunningham who commanded this camp from June 1944 to July 1945 goes much credit for the good work done there.

With the arrival of the 6th Armoured Division in Italy in April 1944, about 2300 CCs came into this area. These men had specifically been selected from the original complement of over 6 $000 \mathrm{CCs}$ who had arrived in Middle East theatre with the Division. They were all serving in noncombatant capacities and were mostly em- ployed on menial duties, except in "Q" services where there were many MT drivers and in the two field ambulances where there were CC stretcher bearers. Naturally in these inconspicuous duties the CC with the Div got little publicity with the result that their contribution to the success of this magnificent fighting force was not fully appreciated outside the Division itself and the small circle of men concerned with the general direction of our war effort. The stretcher bearers as a class often came into the limelight because of the spectacular nature of their duties. The following exploits are typical of the gallant work done by the CC stretcher bearers :-

"C319812V L/CPL WILLIAM CLOETE (MM) - In Oct 44, the battalion which he was in attacked enemy positions on Monte Stanco, and the Coy to which L/Cpl Cloete was attached came under heavy artillery and mortar fire which pinned down the leading platoon. He led forward his stretcher bearers to attend casualties, and in the face of persistent mortar fire he himself carried out no fewer than ten men who had been wounded. Again and again he went back to the platoon and his calm demeanour and courage inspired his team to great heights of endurance."

\section{"M16468V L/CPL SOLOMON FILLIES} $(\mathrm{MM})$ - In the attack on the dominating position of Monte Stanco (Italy) in Oct 44, L/Cpl Fillies, a stretcher bearer, was operating with a platoon in action against the enemy.

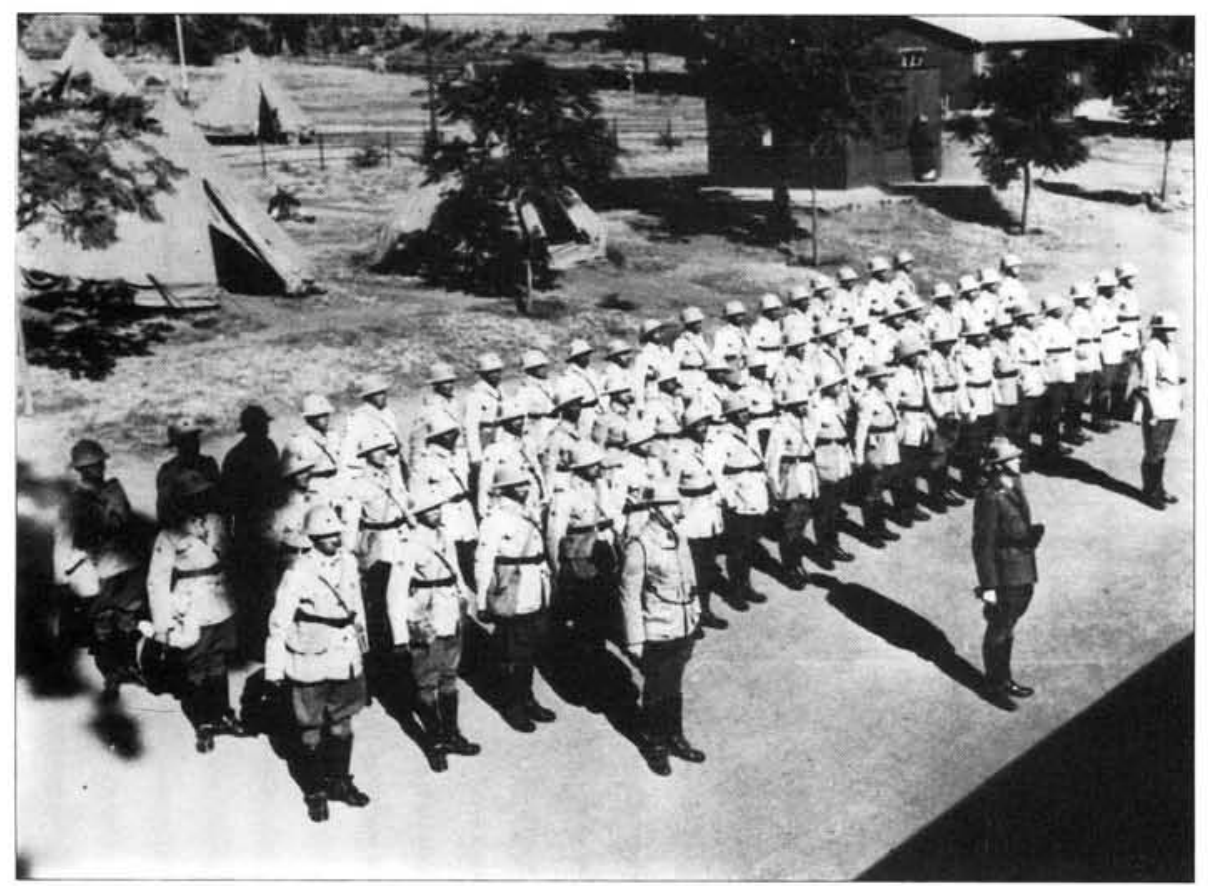

The "Unite for Victory parade" in Johannesburg. The members of the Cape Corps Veterinary and Remount Services pictured here, led the NEAS Contingent at the parade. 
As they moved into action the platoon was suddenly pinned down by very heavy and accurate machine gun fire. The Platoon Commander went forward to investigate and was mortally wounded. Without hesitation and in the face of deadly automatic fire, $\mathrm{L} / \mathrm{Cpl}$ Fillies worked his way forward to where the wounded officer lay and rendered first aid. While engaged in bandaging, snipers were firing at him, but he calmly finished his work and managed to get the casualty out of danger. His fine conduct was an inspiration to all."

Both of these men were awarded the Military Medal for their bravery. A number of other CCs in the Division also gained Military Medals; their citations may be read in the official Honours and Awards lists.

In the wake of the SAAF Squadrons, 6th Division and non-divisional Units followed such auxiliary units as hospitals, convalescent depots and leave camps. 102 SA General Hospital (at Bari) and 106 SA General Hospital (first at Benevento and then at Rome) each brought over $94 \mathrm{NMC}$ and $1 \mathrm{SA}$ Convalescent Depot (Rome) had 55 NMC. These men were employed as batmen, cooks, hygiene workers, motor transport drivers, guards and also as nursing orderlies in the two hospitals. They worked consistently and well until the end of the war in Italy and earned the praise of the White personnel of these medical units.

At the time of the attack on the Gustav line in Italy (stretching roughly from Pescara on the Adriatic to Cassino on the Mediterranean side) at the end of May 1944, the Union Defence Force in the Central Mediterranean theatre had more or less reached its peak strength and then included 2700 NMC with 28 SAAF formations and some non-divisional units and about 2500 CCs mainly with the 6th Armoured Division and a small number with non-divisional and SAAF units. With a strength of over 5000 in Italy these soldiers represented about $20 \%$ of the total NEAS strength outside the Union; the other $80 \%$ having being left to serve in the Middle East Forces.

Although their numbers were never great in Italy the NEAS members nevertheless made a material contribution towards the total Union Defence Force war effort there. The conclusion of the Italian campaign found them amongst the most advanced elements of the divisional units and SAAF formations carrying out the final assault.

Soon after the end of the war in Europe the evacuation of Non-Europeans to the Middle East began and progressed so successfully that at the time of writing only $2000 \mathrm{NMC}$ committed to extended service with occupational units of the SAAF and about $500 \mathrm{CC}$ and NMC awaiting evacuation to the Middle East still remained in Italy.

Let us now return to North Africa and the Middle East and trace the history of the NEAS there.

In March 1944, 104 Cape Corps Battalion arrived and took over security guard duties of military installations in widely scattered areas from Algiers to Bone. This was important work as it released highly trained and much needed Allied fighting men for the Italian campaign. 104 Battalion was a new unit organised on the usual Security basis (approx 700 CCs about 35 Officers and White non-commissioned officers, only in the positions of warrant officers and quartermasters). The unit was inexperienced, arrived in a newly liberated country bristling with problems such as food and clothing shortages and a certain amount of lawlessness (the after effects of war) and a complete lack of colour bar. The unit experienced many teething troubles which were aggravated by the fact that it had a particularly troublesome complement of about $30 \mathrm{CCs}$ included in its ranks.

The bulk of these $30 \mathrm{CCs}$ ultimately landed up in Punishment Centres with sentences ranging from 28 days to 6 months detention. However, in spite of difficulties the Cape Corps did excellent work in that area until it was withdrawn for similar duties to Raffa (on the border between Palestine and Syria) in October 1944.

In May 1944 the SAEC Airfield Construction Group, with $250 \mathrm{CCs}$ in each of 157 and 159 Works Companies and $50 \mathrm{CCs}$ in each of 30 and 32 Road Construction Companies (which constituted the Group) landed at Oran and proceeded to Rabat in Morocco where it started on the construction of one of the most modern airfields in Africa at Rabat Sale near Casablanca. The job involved the laying down of long and wide modern runways capable of taking the biggest aircraft, the erection of a control tower on the field and building of living quarters, ablutions and hospital for the aerodrome staff. It was a big and intricate job, but the skilled South African Engineers ably assisted by over 600 skilled, semi-skilled and unskilled CCs had completed this splendid work by the end of 1944 when the units moved back for further duty in Tripoli and in the Middle East. The units moved overland from Casablanca to Algiers (quite an achievement during the winter condi- 
tions) and from there they went by sea to Tripoli West (in the case of 159 Works Coy) and the Middle East (in the case of all other units) via Italy. During the evacuation all CCs of the SAEC Airfield Construction Group - over 600 of them - were handled in No 4 NE Leave and Transit Camp at Sidi Ferruch (15 miles west of Algiers) and No 2 Non-European Leave and Transit Camp at Bari.

When the SAAF Fighter and Bomber Squadrons moved to Sicily with the invading Allied forces, 28 SAAF Transport Squadron moved from its previous base in Tripoli to the strategically better placed drome at Maison Blanche outside Algiers. This is the only squadron which retained its CC Ground Defence Flight of 62 details. In addition it also had 120 NMC working in the same capacity as NMC in other SAAF units. CC and NMC had been with this squadron since its arrival in $\mathrm{ME}$ and their services were retained for a considerable time as this unit was still operationally committed. During its early Middle East history there was some friction between the CC and NMC in 28 Squadron but it was mainly caused by a small number of trouble makers in both Corps. After their removal both CC and NMC settled and did a fine job in the Squadron. This is one of the examples of how racial difficulties can be overcome if there is a will to do so. In this Squadron NMC, Cape Corps and Whites have been working in harmony side by side for over two years, each section supplementing the other for the benefit of the whole.

Returning to the Delta in Egypt, Western Desert, Palestine and Syria let us see what happened there after the cessation of hostilities in Africa.

In May 1943 the newly formed 6th Armoured Division arrived in the Desert at Katatba with nearly 7000 Cape Corps. The Division was anxious to replace as many Cape Corps as possible with combat soldiers before being committed to battle. Accordingly plans were made to divert the redundant CCs into the most useful channels. General Headquarters Middle East needed security battalions and motor transport companies to relieve combatant troops required for the Italian campaign, so it was decided to form two CC battalions (101, $103)$ and 156 Works and Construction Coy, 136, 137, 138 and 139 CC MT Coys with the CCs who were shed by the division.

All Officers and White NCOs for 101 and 103 Bns and for 136 and 137 CC motor transport companies were despatched from the Union and skilled personnel for 138 and $139 \mathrm{CC}$ motor transport companies were supplied from the disbanded NMC motor transport companies, while Engineer officers and non-commissioned officers for 156 Works Company were supplied by the SAEC.

The formation of these new units commenced in June 43 in the NEAS Depot at Garawi. With its past experience, improved training facilities and increased staff, the depot handled the initial training of the personnel with skill and efficiency. Very soon 101 Cape Corps Battalion with Lt Col E Foxon in command, had been welded into a smart and efficient unit. This battalion, which had vainly hoped that it and other CC battalions might be assigned to a combatant role in Europe or even the Far East, was disappointed when on completion of its infantry training it was consigned to static guard duties at Geneifa, about halfway between Ismalia and Suez. It was soon joined by 103 Battalion which had been doing security guard duties at Raffa in Palestine, but had been relieved by 104 CC Battalion from Algiers. About a year later these two battalions were joined by two further battalions, viz 105 and 6 Cape Corps battalions from the Union. The formation of these CC battalions was another experiment with Non-European manpower and the usual teething troubles were experienced. Men had to be sorted out and often tried in various posts until they fitted in usefully; NCOs who commanded the respect and confidence of the men had to be painstakingly selected and an untried war establishment had to be adopted and guarded before the units could function efficiently. However, these were difficulties which were encountered before; they were soon overcome and the battalions developed into efficient and dependable units. Their duties were heartbreakingly monotonous and they were required to serve in a trying place from a climatic point of view. Carrying on efficiently day after day therefore called for a lot of moral courage from both officers and men.

The steadfast and efficient service of these six CC battalions (ie 101, 103, 105 and 6 battalions on guard duty at Geniefa; 102 on Aerodrome Defence duties in Cyranaica and 104 on security guard at Raffa) carried on. Their dedication to duty was to the credit of the UDF in general and the Cape Corps in particular.

Although these men clamoured for, and genuinely desired, to take a more active part in the war in a combatant role, their relegation to less conspicuous but nevertheless vital work, did not affect their efficiency as soldiers. They did their job well and their contribution to the total war effort was important. These battalions are now 
in the process of dissolution and their personnel are being returned to their demobilisation grounds in the Union.

The four new Cape Corps motor transport companies $(136,137,138$ and 139) formed during September and October 1943, were used to replace four NMC motor transport companies (viz $203,204,206$ and 207) in order to man the UDF commitment of 7 motor transport companies to General Headquarters Middle East. These four NMC motor transport companies could not be maintained as their personnel had qualified for Union Leave after three years serv-
Gaza and 139 Company was sent to operate in the Benghazi area. These Cape Corps companies soon became efficient transport units and did yeoman work in their respective areas. They were constituted on more or less similar lines to their predecessors (the NMC companies) except that they had less European personnel and 40 more Cape Corps details. The difference in the number of white soldiers is explained by the fact that each of the 24 subsections in a Cape Corps company operated under a CC corporal whereas the NMC subsections were in the charge of white sergeants. In view of the shortage of suitably qualified arti-

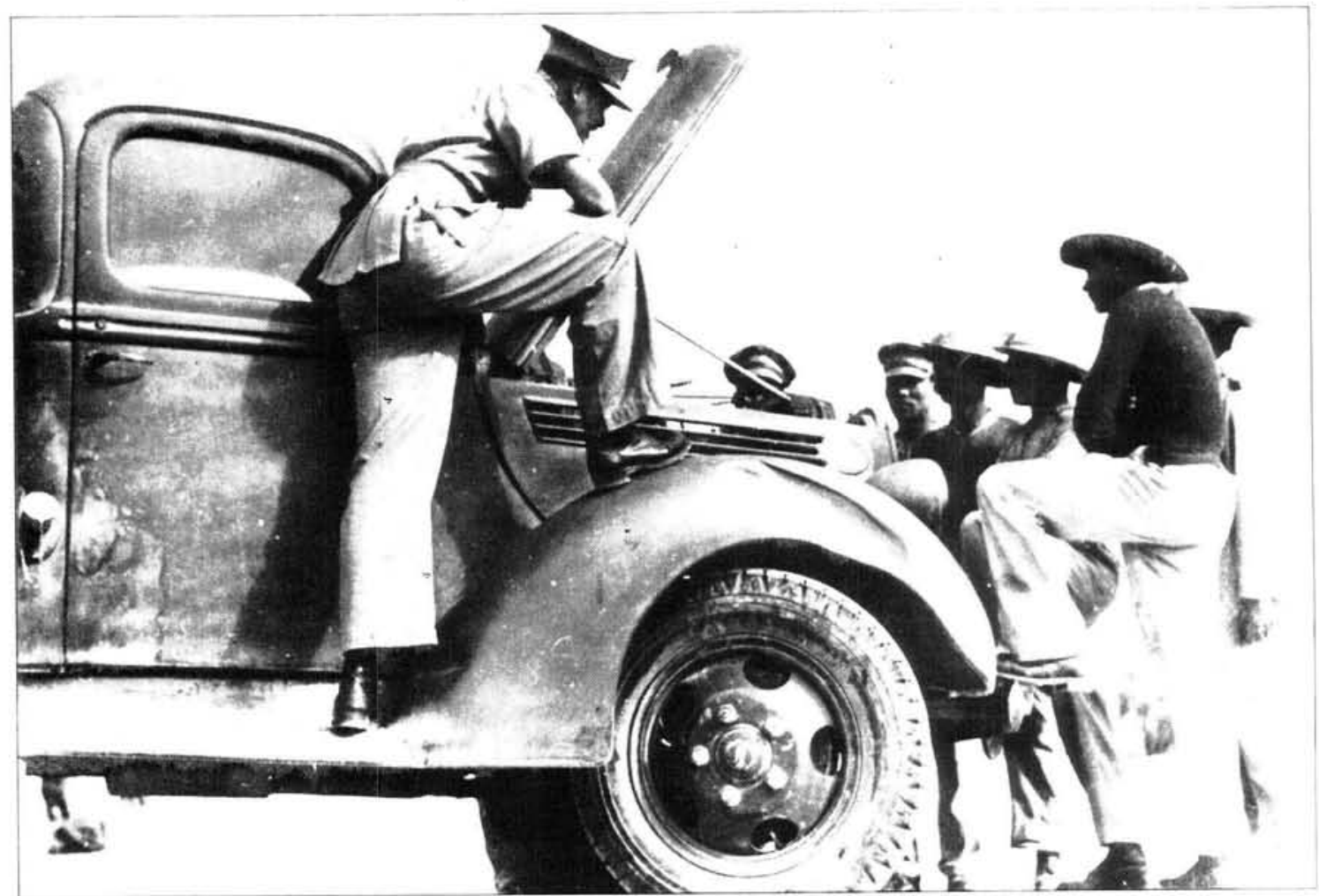

A team of drivers receive instruction in vehicle maintenance.

ice up north and because no NMC replacements could be supplied from the Union.

As had been the case with the breaking up of the CC motor transport companies which came through East Africa, it was a hard blow to officers and men to see these fine units disintegrating. Soldiers had by this time, however, become more reconciled to these inevitable demands of war and appreciated the fact that the progress of the war demanded constant changes and that the NEAS, like other branches of the service, had to adapt itself to meet new commitments, eg the increasing number of NMC drivers required by the expanding SAAF.

Of the new Cape Corps motor transport units, 136 and 137 companies, were committed to service in the Delta while 138 Company went to sans in the UDF, both the NMC and CC companies had a RASC (British) Workshop Platoon attached to it.

The maintenance of Lines of Communications from Suez to Aleppo in Syria and Tripoli in Libya was no mean task. The Middle East, even after the Axis force had been driven out of Africa, remained of vital strategic importance, both for the prosecution of the war in the Pacific as well as supporting the advance in Italy. It was, in fact, the main arsenal, workshop, rest, training and reinforcement centre of all the Allied forces operating in the Mediterranean theatre. Vast quantities of war materials, troops and foodstuffs had to be guarded and transported to units in the area and to the ports for shipping to Italy, Greece and the Pacific. Vital military installations, workshops and large numbers of Axis prisoners of war had to be 
guarded, and aerodromes had to be built, maintained and guarded. Internal security in Egypt, Palestine, Syria, Cyrenaica and Tripolitania had to be safeguarded. This was no mean task as the area involved stretched from the Delta for a thousand miles northeast to the Turkish border and for nearly two thousand miles west to Tripoli and beyond. To this enormous task the NEAS contributed about 15000 NMC and CC personnel serving in the following units :-

Few soldiers would choose Line of Communication or base duties if they were given the option between that and duty in more active units. The position is worse when such duties have to be performed in such inhospitable territory as the Western Desert. However, the job had to be done and to the NEAS fell the task of undertaking the lion's share of the UDF allocation of such duties. This fitted in with the UDF policy which was to send Whites rather than Blacks out of Africa and materially assisted by the British who could withdraw an equivalent number of troops for duty elsewhere.

The Non-Europeans accepted the position and settled down to the job. The work was very important but often heartbreaking in its monotony. The duties were exacting and called for moral courage as well as physical fitness and mental alertness. Try and visualize Cape Corps linesmen maintaining telephone lines in the blazing sun at Sidi Barrani, NMC drivers ferrying three tonne vehicles from Suez to Tripoli West (nearly 2000 miles) and Cape Corps guards walking sentry beat round lonely aerodromes in the desert or seething prisoner of war cages in the Delta and you will get some conception of the gruelling tasks these men were called upon to do month after month, almost year after year. These NEAS servicemen in the Middle East theatre served their country faithfully and well.

This account will show that although Cape Corps and NMC soldiers in this war were seldom in the limelight they did a sterling job and qualify for an honoured place in South Africa's proud war record.
They were paid the following tribute by Major Geneneral F.H. Theron, the General Officer Administration Union Defence Forces Central Mediterranean and Middle East forces, when the war ended in Europe:

"The cessation of hostilities in Europe finds large numbers of NMC and Cape Corps troops among the vanguard of our victorious troops in the Mediterranean theatre of operation, and many more back in the Union after long spells of service in the field during the early and most difficult part of the war. To all of you as well as those who could not get nearer the enemy because their services were needed in the Union, I send my message of congratulation and rejoicing on this long awaited day of Victory in which you have played such a splendid and worthy role.

"Wherever you went you made the Orange Flash and the Cape Corps and NMC badges symbols of determination and efficiency. Those who did their duty in the Union, the men who drove thousands of vehicles from South Africa to the Middle East and Italy, the workmen who built roads and aerodromes from Cairo to Casablanca, the men in the Air Force and the very gallant stretcher bearers and their comrades who served so well in our 21st, 2nd and 6th Divisions, as well as all the others who worked devotedly in less conspicuous posts behind the line, can well be proud of the very fine record of service that the NEs maintained during the war. Your devoted service will always be remembered with appreciation in South Africa.

"You have seen many lands and learnt many things, above all you have learnt to live and work in unity with men of all creeds and colour. Do not forget this ideal of service now that freedom has been won, but rededicate yourselves to the high ideals for which you have fought and triumphed and for which so many have suffered and died, and let the ideal of service which you have learnt in this war dominate your lives when you return to our country to build a proud and united South Africa." 